\title{
Eski Anadolu Türkçesi Özellikleri Gösteren Bir Kıssa-yı Yûsuf
}

\section{The Joseph Parable Which Showing Medieval Anatolian Turkish Properties}

\begin{abstract}
Ali Cín ${ }^{*}$
Didem AKYILDIZ ${ }^{* *}$

$\ddot{O}_{z e t:}$ Kıssa-yı Yusuf, Hz. Yusuf peygamberin ibret dolu hayat hikâyesinin aşk, sevgi, umut, ihanet, kıskançlık, nefret gibi insanî duygularla zenginleştirilmesiyle birlikte yüzylllar boyu çeşitli kişilerce çeşitli biçimlerde kaleme alınmış ve zevkle okunmuş dinî boyutlu bir hikâyedir. Edebî sahada, Kıssa-yı Yûsuf, Yûsuf Mesnevisi, Yûsuf u Züleyha, Yûsuf u Zelîha gibi çeşitli adlarla anılan hikâyenin geçmişten günümüze bu kadar sevilmesi ve rağbet görmesinde, hikâyenin kaynağının kutsal kitaplara dayanmasının payı büyüktür. Tevrat ve bazı bölümleriyle İncil'de de dini, ahlaki ve felsefi boyutları içermesinden ötürü insanlığa yön vermesi için bahsedilen bu hikâye, Kur'ân-1 Kerim'de "ahsen'ül-kasas" yani "kissaların en güzeli" olarak vasıflandırılmaya layık görülmüștür. Hem Batı hem Doğu edebiyatlarında birbirinden güzel örnekleri bulunan bu hikâyenin, Türk Edebiyatında ilk örneğinin görüldüğü 13. yüzyıldan günümüze birçok manzum ve mensur Klssa-yı Yusuf yazılmışıı. Bu makalede, Eski Anadolu Türkçesi özelliklerine sahip, Muhammed bin Hüseyin tarafindan istinsah edilen 3485 beyitlik Kıssa-yl Yûsuf mesnevisi ve eserin dil özellikleri hakkında bilgi verilecektir.
\end{abstract}

Anahtar sözcükler: Klssa-yı Yûsuf, Yûsuf ve Züleyhâ Hikâyesi, Eski Anadolu Türkçesi, Yûsuf ve Züleyha Mesnevîsi, Yûsuf Hikâyesi

Abstract: The Parable of Joseph, a religious story has been rewritten by different people in various ways over the course of centuries. This exemplary story of the Prophet Yusuf is rich in love, hope, jealously, hate and betrayal. In the field of literature being based upon the Holy Books, this story, also entitled, Kıssa-yı Yusuf, Mathnawi of Yusuf, Yusuf and Zuleyha, Yûsuf u Zelîha was retold for centuries. This story, found also in the Old Testament and Bible due to its complex of religious, ethical and philosophical dimensions, was worthy of consideration as "the best story" in the Holy Qur'an and there are fine examples in both Western and Eastern literatures. From the $13^{\text {th }}$ century, when the first example in Turkish literature was written, many examples of the Parable of Joseph were written in both verse and prose. This article addresses the 3485 couplet poem of the Parable of Joseph written by Muhammed bin Hüseyin within the context of Medieval Anatolian Turkish and it's linguistic properties.

Keywords: The Parable of Joseph, The Story of Joseph and Zuleyha, Ancient Anatolian Turkish, The Mathnawi of Joseph and Zuleyha, The Story of Joseph

\section{Giriş}

Türk edebiyatında Kıssa-yı Yûsuf, Yûsuf u Züleyha, Yûsuf u Zelîha gibi adlarla bilinen bu hikâye, genel itibariyle Yûsuf peygamberin hayat hikâyesini konu alan, asırlar boyu birçok kimse tarafından çeşitli biçimlerde kaleme alınmış ve zevkle okunmuş bir hikâyedir.

\footnotetext{
* Yrd. Doç. Dr., Akdeniz Üniversitesi, Edebiyat Fakültesi, Türk Dili ve Edebiyatı Bölümü, alicin@akdeniz.edu.tr

** Arş. Gör., İstanbul Üniversitesi, Edebiyat Fakültesi, Türk Dili ve Edebiyatı Bölümü, didemakyildiz07@gmail.com
} 
Yûsuf ve Züleyha hikâyesinin esasına dair belirtiler, tarihin ilk çağlarına kadar uzanmaktadır (Ayan, 1997, 31). Hikâye, ilk olarak bazı unsurlarıyla M.Ö. XIV. yüzyılda eski bir Mısır hikâyesinde yer almıştır. Ayrıca Tevrat'ın ilk kitabı "Tekvin-bab 0-50"de de geniş biçimde yer alırken İncil'de ise “Resulllerin işleri, bab 7”de kısaca konu edilmiştir (Çetin, 2000, 109).

İslam çağındaki Türk edebiyatında hikâye türünün ilk kaynağı, Kur'an'daki kıssalar, dervişler arasında yayılmaya başlayan enbiya ve evliya menkıbeleri, din ulularının efsaneleştirilmiş kişilikleri ve kahramanlıkları çevresinde beliren söylentilerdir (Levend, 1967, 71). İşte bu hikâyelerden biri de Kur'an-1 Kerim'de Yûsuf sûresinde 111 ayette anlatılmış, baştan sona tam bir hikâye hüviyetine sahip tek hikâye olan Klssa-yı Yûsuf'tur ki bu hikâye Kur'an-1 Kerim'de “ahsenü'l-kasas" yani "klssaların en güzeli" olarak vasıflandırılmaya layık görülmüş bir hikâyedir.

Kutsal kitaplarda yer almasıyla birlikte, içeriğinde evrensel tema ve duyguları barındırması nedeniyle de hem Batı hem de Doğu'da ünlenmiş bu hikâyenin kaynağını -kesin çizgilerle ayırmamakla beraber- Batı'da Tevrat, Doğu'da yani, Arap, İran ve Türk edebiyatlarında ise Kur'an-1 Kerim oluşturmaktadır.

Kıssa-yı Yûsuf yazma geleneğinin Arap ve Fars edebiyatlarından sonra Türk edebiyatındaki ilk örnekleri 13. yüzyıla aittir. Bu dönemde yazılan eserler genel olarak "Kıssa-yı Yusuf", "Kıssa-yı Yusuf u Züleyha" şeklinde adlandırılmış olup isimlerinden de anlaş1lacağı gibi hikâyenin daha ziyade bir peygamber kıssası, bilhassa Kur'an-1 Kerim'in vasıflandırmasıyla "ahsenü'lkasas" olması önem taşır. Bu döneme ait eserler daha ziyade Kur'an, tefsir, hadis ve kısmen Tevrat referans alınarak yazılmıştır (Türkdoğan, 2011, 57).

13. yüzyılın ilk yarısında (H. 630 / M. 1232) kaleme alınan ve Türk edebiyatının ilk Kıssa-yı Yûsuf'u olma özelliği taşıyan eser, "Harezmli Ali", "Kul Ali", "Kul Gali" adlarıla anılan Ali'nin Kıssa-yı Yûsuf'udur (Cin, 2011, 59). Dörtlüklerle ve hece vezniyle yazılmış olan Ali'nin eseri, bünyesinde hem Doğu hem Batı Türkçesi dil özelliklerini barındırmasıyla "karışık dilli eserler" olarak da bilinen eserler arasında mühim bir rol oynar. Ali'nin eserinden sonra Anadolu'da mesnevi türünde, aruz vezniyle yazılmış ilk Yûsuf u Züleyhâ olma özelliğine sahip bir diğer eserimiz, Şeyyâd Hamza'ya ait Yûsuf u Züleyhâ' dır. Eserini 13. yüzyılın sonunda sade bir dil ile yazan Şeyyâd Hamza'nın ardından 14. yüzyılda Süle Fakih, Erzurumlu Darîr gibi şairlerin zamanında çok sevildiği anlaşılan Yûsuf u Züleyhâ hikâyeleri gelir. Yukarıda başlıcalarını saydığımız mesnevilerin dışında çoğunluğu manzum olan daha başka Yûsuf u Züleyhâ hikâyeleri de mevcuttur (Ayrica bkz., Dolu, 1952, 423).

Bilindiği üzere 13. ve 14. yüzyıllarda yazılmış olan bu mesnevilerde dil oldukça sade ve anlaşılır bir niteliktedir. Ayrıca bu mesnevilerde kullanılan vezinlerde bazen müellifin kendisinden bazen de müstensihten kaynaklanabilecek kusurların bir hayli fazla olması gibi nedenlerden ötürü "Halk Tipi Mesneviler" (Çelebioğlu, 1999, 45) kategorisinde sıralayabileceğimiz bu mesnevilerle birlikte artık 15. yüzyıldan sonra Molla Cami'nin etkisinin görüldüğü edebi yönünün ağır bastığı mesnevilerle karşılaşılmaktadır.

15. yüzyılda yaşadığı bilinen Hamdullah Hamdi'nin kaleme aldığı Yûsuf u Züleyhâ hikâyesi, mesnevi tarzında yazılmış edebi değeri en yüksek Yûsuf u Züleyhâ hikâyesi olarak kabul edilmektedir. Bu yüzyıl ve bu yüzyıldan sonra dönemin siyasi ve edebi anlayışıyla birlikte gerek Molla Cami'nin tesiriyle gerek Hamdullah Hamdi'nin etkisiyle birçok Yûsuf u Züleyhâ mesnevisi kaleme alınmıştır.

Görüldüğ̈̈ gibi Yûsuf u Züleyhâ yazma geleneğinin Türk edebiyatındaki seyrine bakıldığında ilk mesnevilerde Kur'an kıssasından bir ders çıkarma amacı güdülmüş olduğu; 15-16. yüzyıllarda ise kıssanın entrik yapısı zengin, çift kahramanlı bir aşk hikâyesi olarak beğenildiği ve gerek tahkiye, gerek dil ve üslup acısından zirve eserler verildiği dikkatleri çekmektedir. 17. 
yüzyıla gelindiğinde, artık, bu konu çok işlenmiş, çok söylenmiş bir başka şair tarafından aşılması güç bir noktaya çekilmiştir (Türkdoğan, 2011, 65).

$\mathrm{Bu}$ eserlerle birlikte inceleme konumuzu oluşturan Kıssa-yı Yûsuf mesnevisinin elimizdeki yegâne nüshası 18. yüzyıl Osmanlı Döneminde yazılmıştır.

\section{Eserin Yazarı}

Milli Kütüphane'de 06 Mil Yz A 9605 numara ile kayıtlı bulunan nüshası üzerinde inceleme yaptığımız bu eserin müellifi hakkında kesin bir bilgi maalesef edinilememiştir. Bilindiği gibi Türk edebiyatında asırlar boyu farklı kişiler tarafından çeşitli Kıssa-yı Yûsuf'lar vücuda getirilmiştir. Bunların içinde orijinal metinler olduğu gibi bazı metinler nazire olarak yazılmış bazıları da nazire şeklinde olmaksızın birden fazla Kıssa'yı Yûsuf'tan esinlenerek şairin kendinden de bir şeyler katmasıyla yazılmıştır. Öyle gösteriyor ki üzerinde çalışı̆̆ğımız metin de birden fazla Kıssa'yı Yûsuf'tan esinlenerek yazılmış bir eserdir. Eserde Şeyyad Hamza'dan, Erzurumlu Darîr'den ya aynen alınmış yahut bazı farklılıkların bulunduğu birkaç beyit görülmekle birlikte eserde en çok Süle Fakih'in tesiri hissedilmektedir. Şöyle ki eserde toplam yedi gazel geçmektedir. Bunların dördünün makta kısmında "faķi" ismi geçmektedir. Eserde genellikle günlük konuşma dili olarak nitelendirebileceğimiz bir dil hâkimken bahsi geçen bu gazellerde dil biraz daha edebi bir şekle bürünüyor ve eserin genel üslubu biraz daha farklılaşıyor. Bununla birlikte çabalarımıza rağmen Süle Fakih'in eserine maalesef dolaylı yoldan (Çetinkaya, "Aşk Mesnevilerinde Kadın, Yûsuf u Züleyha ve Hüsrev ü Şirin Mesnevileri, 2008) ulaşabildiğimiz için bu eserler üzerinde tam bir mukayese fırsatı bulamadık. Aşağıda bahsi geçen gazellerin makta kısımları gösterilmiştir.

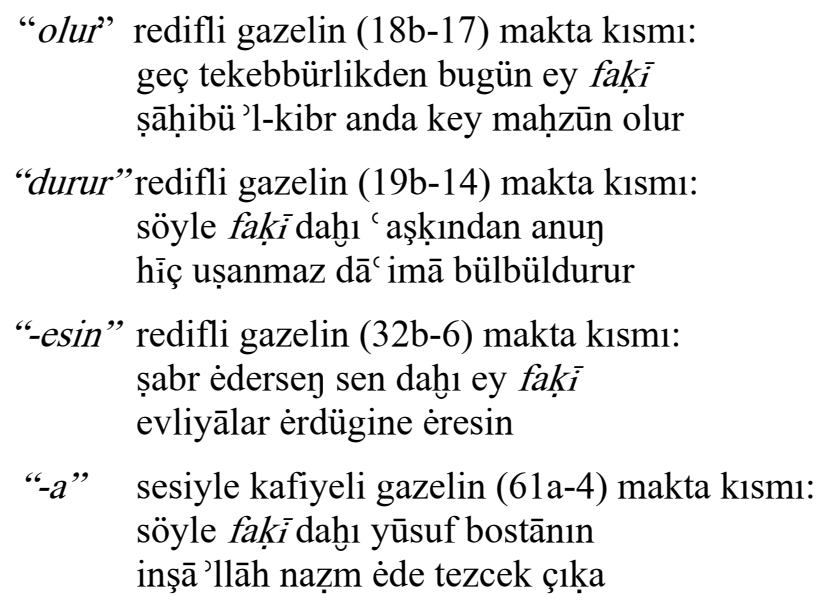

Bu gazeller dışında şair -bir konudan diğer konuya geçiş beyitleri, ara beyitler olarak adland1rabileceğimiz beyitlerden sonra- $42 \mathrm{a}-2$ numaralı beyitte, yine faḳi ismini zikretmiştir:

söyle fakinü̈n yazugiunı dilim yarlığaġl ey kerīm ey rahīim

Üzerinde çalış1lan nüshanın müstensihine gelince, eserin son beyitinde (100a-17) müstensihi olduğunu düşündüğümüz Muhammed bin Hüseyin'in adı geçmektedir.

"el-lugat-i ketebehū muhammed bin hü̈seyn gaferu 'l-lāh

lehü ve livālideyni ve li cemī 'ü 'l-mü 'min̄in'”

Müstensih olduğunu düşündüğümüz bu kişi hakkında da hiçbir kayıt bulunamamakla birlikte, eseri yazış tarzına bakıldığında çok iyi bir müstensih olmadığı söylenebilir. Ayrıca inceleme yaptığımız eserin tek nüshası olan Milli Kütüphanede 06 Mil Yz A 9605 numaralı kayıtta yer 
alan yazmanın arkasında yine aynı kişinin kaleminden çıkmış 204 beyitlik bir Kıssa-yı Kerbelâ bulunmaktadır. Bu eserin sonunda da "śăhib ü mālik Molla Muhammed el-hakìì ibn-i Hüseyn Efendi-zāde" ibaresi geçmektedir.

\section{Eserin Yazılış Tarihi}

Eserin yazılış tarihi bir beyit içerisinde geçmemekle birlikte son varağın alt köşesinde Arap rakamlarıyla sene 1198 yazılmıştır. Dolayısıyla eserin miladi takvime göre 1784 yani 18. yüzyılda yazıldığını söyleyebiliriz.

\section{Eserin Nüshası}

Bugün için eserin elimizde tek bir nüshası mevcuttur. İnceleme konumuzu oluşturan bu nüsha da Muhammed bin Hüseyin tarafından istinsah edildiği düşünülen Milli Kütüphanede $06 \mathrm{Mil} \mathrm{Yz}$ A 9605 numaralı kayıtta bulunan el yazmadır. Bu nüshanın sırtı ve çeharkuşesi kahverengi meşin olup üzeri silikleşmiş, soyulmuş ebru kâğıt kaplı harap bir cilttir. Dış 218x154, iç 180x115 mm ebatlarındadır. Üç ay filigranlı kâğıt türünde bozuk nesih ile yazılmıştır. Her varakta ortalama çift sütun olarak 17 satır vardır. Satır sayısı bazen 16, bazen de 18 olabilmektedir.

Yazma 100+VII varaktan oluşmaktadır. İlk 100 varağı Kıssa-yı Yûsuf'a ayrılmış olup sonundaki VII varakta yine aynı kişinin adının geçtiği Kıssa-yı Kerbelâ bulunmaktadır.

\section{Eserin Şekil Özellikleri}

Eser mesnevi tarzında fâilâtün, fâilâtün, fâilün vezniyle yazılmıştır. Toplam beyit sayısı 3485 olan eserin içinde yedi gazel bulunmaktadır. Bilindiği gibi mesnevi tarzı hikâyelerde konuya doğrudan doğruya girilmeyip önce bir başlangıç, tevhid, münâcât, na't, eserin sunulacağı büyüğe övgü, mesnevinin niçin yazıldığını açıklayan sebeb-i te'lif manzumeleri yer alır. Sebeb-i te'lif bölümleri gelenekseldir. Şair burada eserini niçin yazdığını anlatır. Bundan sonra "Agaz-ı Dastan" başlı̆g altında maksada geçilerek hikâyeye girilir (Levend, 1967, 73).

İncelenen Kıssa-yı Yûsuf mesnevisinde, sebeb-i telif olarak addedeceğimiz aşağıda gösterilen ilk dört beyit dışında, klasik bir mesnevide bulunan diğer bölümlere rastlanılmamıştır. Görüldügü gibi kısa bir giriş yapılarak hemen hikâyeye geçilmiştir.

\begin{tabular}{|c|c|}
\hline $1 \mathrm{a}-1$ & $\begin{array}{l}\text { kıssșasin yūsufun şerḥ eylegil } \\
\text { sergüzeştin evvel ăhir söylegil }\end{array}$ \\
\hline $1 \mathrm{a}-2$ & $\begin{array}{l}\text { türkī dilince anı kılgııl edā } \\
\text { hisșse ala ḳamu yohsul gedāa }\end{array}$ \\
\hline $1 \mathrm{a}-3$ & $\begin{array}{l}\text { mahża tefsiri rivāyet eylegil } \\
\text { her ne söylersen kıșsașindan söylegil }\end{array}$ \\
\hline $1 \mathrm{a}$ & $\begin{array}{l}\text { hem ulular meclisinde söylene } \\
\text { nazmla kısșa hikāyet eylene }\end{array}$ \\
\hline
\end{tabular}

Şair bu ilk dört beyitte, eserini halk tabakasının rahatlıkla anlaması için Türkçe söylediğini, ilim irfan sahibi zatların bulunduğu meclislerde de okunması için nazımla kaleme aldığını belirtmektedir. Ayrıca yine görüldüğü üzere şair eserinin inandırıcılığını ve değerini artırmak için yazdığı her şeyin Kur'an-1 Kerim'deki Yusuf Peygamberin kıssasına ve tefsirlere dayandırdığını söylemektedir. Bilindiği gibi bu kıssa ile ilgili ayetler ve hadisler kıssanın önemini artıran başlica etkenlerdir. Yusuf suresinin 7. ayeti (meal olarak) "Yusuf ve kardeşlerinin kissalarina onu soranlar için bir takım ibretler vardır" şeklinde iken tefsirlerde bu ayet, "mahzunlara ferahlık, gafillere nasihat, müminlere şadilik ve sevinç verir. Bunun okunması Allah'a tevekkülü arttırır. Kaza ve kadere olan imanı kuvvetlendirir. Sadakati ve kötülüklere karşı sabrı tavsiye eder" 
açıklamaları içerir (Ayan, 2009, 227). Şair bundan ötürü olsa gerek eserin çeşitli yerlerinde bunu okuyucuya hatırlatmıştır:

\begin{tabular}{|c|c|}
\hline $41 b-15$ & $\begin{array}{l}\text { bundan artuk destānlar çok durur } \\
\text { dinleyenlere sevābı yoḳ durur }\end{array}$ \\
\hline $41 b-16$ & $\begin{array}{l}\text { illā bunı dinleyenlere șevāb } \\
\text { vériserdür ahı allāh bi-hesesāb }\end{array}$ \\
\hline $41 b-17$ & $\begin{array}{l}\text { Zīrā bu destānı allāh söyledi } \\
\text { cebrā'îl hem bunı vașf eyledi }\end{array}$ \\
\hline $42 a-1$ & $\begin{array}{l}\text { kısșșalarū görklü yegrekidi } \\
\text { kim oḳursa yazugun yorurıdı }\end{array}$ \\
\hline $69 b-15$ & $\begin{array}{l}\text { mest oluban gözlerimüz sürelüm } \\
\text { yūsufü sözlerini hem yazalum }\end{array}$ \\
\hline $69 b-16$ & $\begin{array}{l}\text { söz düzelüm yazariken sözile } \\
\text { oḳuyanlar dinleyenler arıla }\end{array}$ \\
\hline $69 b-17$ & $\begin{array}{l}\text { kamu bostānlar șon ucı bozıla } \\
\text { illā yūsuf bostānı ebed ḳala }\end{array}$ \\
\hline $70 a-1$ & $\begin{array}{l}\text { tanrı ögdi yūsufun bostānını } \\
\text { tanrı dédi yūsufün destānını }\end{array}$ \\
\hline $70 a-2$ & $\begin{array}{l}\text { kim mahāne bulısar bu destāna } \\
\text { mahāne bulan kişi oda yana }\end{array}$ \\
\hline
\end{tabular}

\section{Eserin Dil Özellikleri}

Üzerinde çalışılan nüsha muhtemeldir ki 18. yüzyılda istinsah edilmiştir. Genel itibariyle Eski Anadolu Türkçesi dil özelliklerine sahip olan eser, bazı kelimelerde Eski Anadolu Türkçesinde görülmeyen düzleşmeleriyle de dikkat çekmektedir. Bununla birlikte eserin dili oldukça sadedir. Adeta halk hikâyesi anlatılır biçimde bir üsluba sahiptir diyebiliriz. Eserde aynı zamanda, sözlüklerde yer almayan deyim ve atasözü geçmekle birlikte bazı yerel söyleyişler de görülmektedir.

\subsection{Eserin İmla Özellikleri}

Yazmanın imlasında bir bütünlük yoktur. Bir kelimenin birden fazla yazımının oluşu, sıklıkla görülen bir hadisedir. Eserde Türkçe kelimelerdeki ünlülerin çoğunun gösterilmesi ve yabancı asıllı bazı kelimelerin ünlülerinin de kaynak dildeki yazımına bağlı kalınmadan bütün ünlülerinin yazılması gibi etkenler, bize bunun ya Uygur yazı geleneğinin etkisiyle olabileceğini ya da müstensihin imla bilgisinin pek yeterli olmadığını düşündürmektedir. Eser imla, ses ve şekil bilgisi bakımından değerlendirildiğinde şu sonuçlara ulaşılmıştır:

Metinde ünsüzlerin yazılışı:

/ $\boldsymbol{c} /$ ünsüzü bulunan kelimelerde bu ünsüz genellikle ç (๘) şeklinde yazılmış, ancak bazen ayrım yapılmadan c (ج) ile de gösterilmiştir.

/ p / ünsüzü, kelime başında ve içinde p (ب) harfi ile karşılanırken kelime sonunda daha ziyade b (ب) harfi kullanılmıştır.

/ s / ünsüzü kalın sıradan kelimelerde düzenli olarak ș (ص), ince sıradan gelen kelimelerde ise s (س) ile yazılmıştır. İstisna teşkil eden kelimeler ise çok azdır: seçüp (صحوب) 1a-8, sarāyda 34a-17, sil (صرايدا) 59b-4. 


\subsection{Eserin Ses Bilgisi Özellikleri}

Eski Türkçede / t /li olan bazı kelimelerin Eski Anadolu Türkçesi metinlerinde /d/ye dönüştüğü bilinmektedir. Bu durum bu metinde de söz konusu olup bazen aynı kelimenin her iki şekilde yazımıyla karşılaşmaktayız:

/ t / ünsüzünün korunduğu kelimeler:

țag-, țam-, țamu, țamar, țanuklık, țanla-, țap-, țapu, țart-, țaşla-, țaşra, țatlu, țavul, ța, tüttür-, tın-, togra-, ton, tonan-, tonuz, țulun-, țuz.

t- > d- nöbetleşmesinin görüldüğü kelimeler:

dad-, dagitt-, dahı, daşı-, darlık, darıl-, dar, dayan-, dayı, dé-, dede, deg-, degin, degirman, degüşür-, dek, del-, delim, delü, delüh, delür-, dem, demür, denk, deniz, dep-, depele-, depril-, dè-, deve, devşür-, dinsuzın, dirnak, dip, dik-, dil, dile-, dilek, din-, dinel-, dinle-, dinlen-, direk, diri, dirlik, diş, dişi, ditre-, diz, dokun-, dög-, dört, dön-, dös, döse-, dössek, dudak, duzak, dügün, dükel, dükeli, düken-, dün, dür-, dürlü, düş-, dürt-, düş, düşün-, düz, düz-.

Metinde her iki ünsüzle de yazılmıș olan kelimeler:

dag / țag, dagill- / țağll-, dak- / țak-, dal- / țal-, dan / țan, dan- / țan-, daş / țaş, daş- / țaş-, derle- / terle-, dök- / tök-, dökül- / tökül-, dog- / tog-, dogrn / togrn, dol- / tol-, dolu / tolu, doy- / toy-, dur- / țur-, dut- / țut-, duy- / tuy- .

Eski Türkçedeki /k/ ile başlayan bazı kelimeler, Batı Türkçesinde /g/ ye dönmüşlerdir.

k- > g- nöbetleşmesinin olduğu düşünülen kelimeler:

gèce, gèç, geç-, geçür-, gel-, genç, gèrçek, gèrdek, ger-, gemi, gerek, gèrü, get-, getür-, gez-, gibi, gevde, gider-, gir-, gey-, git-, giz, gizle-, gizlü, göç, gök, gökyüzi, gögüs, gökçek, gölge, göm-, göndür-, gönen-, göz, görüş-, göster-, gözet-, gözgü, güç, gül-, güldür-, gümüş, gün, günlik, gündüz, güneş, gürle-, güvegi, güt-.

Günümüzde Anadolu ağızlarında sıklıkla rastlanan ķ-/g- nöbetleşmesinin metinde az da olsa örneği bulunmaktadır. karğ $ı$ kelimesi metinde hem kargl, hem de $\dot{g} a r \dot{g} \iota$ olarak, koy- fiili de hem koy-, hem de goy-biçiminde iki şekilde geçmektedir. Bunların yanı sıra Arapça bir kelime olan

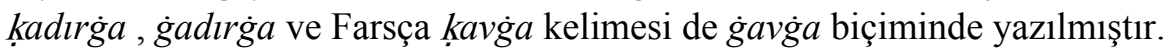

ç/ş nöbetleşmesi, metinde her iki şeklini de gördügümüz bazı fiil köklerinde bulunmaktadır. Bu fiiller şunlardır: geç-/geş-, iç-/işs-, göşs-, aç-/aş-, kaç-/kaş-, saç-/saş-.

Türkçenin her döneminde olduğu gibi, metinde de ünlülerin kalınlık-incelik uyumu bakımından sağlam olduğu söylenebilir. Ancak buna istisna teşkil edecek kelimeler de yok değildir. $-k 1$ lki aitlik eki ḳanki kelimesinde uyuma bağlı şekilde kendini gösterirken dịvārındaki kelimesinde, günümüzde olduğu gibi uyum dişıdır. Günümüzde " $l$ " sesinin inceltici özelliğinden dolayı ince sıradan ekle oluşturulan helal-lik kelimesi metinde helal-lık biçiminde kalın sıradan -lık ekiyle oluşturulmuştur.

Düzlük-yuvarlaklık bakımından ünlü uyumunun Eski Türkçeden beri sağlam kuralları olmadığ bilinmektedir. Türkçenin tarihî dönemleri içerisinde çeşitli sebeplerle yuvarlaklaşmanın yoğun olduğu Eski Anadolu Türkçesi'nde bu uyumsuzluk, kendini daha da kuvvetli göstermektedir. Eski Anadolu Türkçesi dil özelliklerini barındıran bu metin de düzlük-yuvarlaklık uyumundan söz etmek pek mümkün olmamakla birlikte; ḳapıg $>$ kapu, șarı $>$ șaru, țapı $\dot{\mathrm{g}}>$ țapu gibi kelimelerde kelime sonu $-\mathrm{g} /$ - $\mathrm{g}$ sesinin düşmesiyle meydana gelen yuvarlaklaşmalar, demür örneğinde olduğu gibi dudak ünsüzü sebebiyle oluşan yuvarlaklaşmalar, artuk, ayruk,

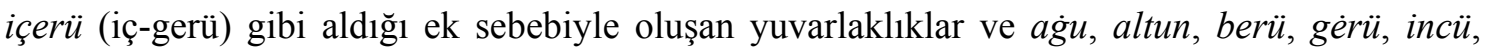
kamu, yılduz, karşu, kayg்u, kendü (bu kelime metninde $10 \mathrm{kez}$ kendi biçiminde uyuma girmiş biçimde karşımıza çıkmaktadır), gibi Eski Türkçeden beri yuvarlak ünlülü kelimeler görülür. Bunların dişında kesüp, ḳğırtuban, ḳldum, bildüm, elimdedür, èrdürdi, etmişdür, geçürdi, 


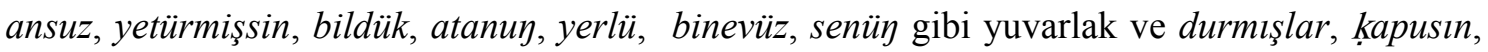
tonı, ḳyumcı, ugrulık gibi düz ünlüye sahip ekler sebebiyle oluşan uyumsuzluklar da vardır.

Metinde Türkçe iki kelimede ön seste /y/ türemesi olmuştur. Bunlardan yeriş- fiili $3 \mathrm{kez}$, yıraks kelimesi ise 2 kez geçmektedir.

Ünlü düşmesi, kelime başında ve daha çok kelime ortasında görülen bir ses olayıdır. Türkçede orta heceler vurgusuz olduğundan kelime ortasında ünlü düşmesi çok fazla meydana gelmektedir. Bu metinde de kelime ortasında ünlü düşmeleri çok sık görülürken, kelime başında ısır- fiili metnin iki yerinde șır- biçiminde karşımıza çıkmaktadır: șıruban 25a-10, 31b-16.

İki veya daha çok heceli kelimelerin sonundaki -g/-g ile eklerin sonunda bulunan -g/-g ünsüzleri Batı Türkçesinde düşmüştür. Metinde bu hadiseye örnek kelimeler olduğu gibi -g-/-g ünsüzünün düşmemiş olduğu örnekler de mevcuttur: "bir maddenin dilde bıraktığı yakıcı tat" anlamındaki acı 21b-8 kelimesinde /g்/ ünsüzü düşmüş biçimde görülürken, "dert, 1ztırap" anlamındaki acı kelimesinde ise $/ \dot{\mathrm{g}}$ / ünsüzü korunmuş bir biçimde acig 83a-14 kelimesi karşımıza

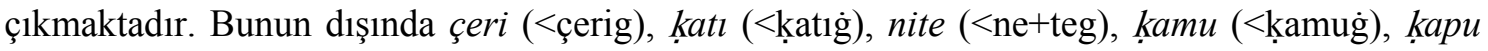
$(<$ ḳapı $\dot{g})$, ölü (<ölüg), țapu (< tapug்) gibi kelimelerde de $-g /-\dot{g}$ sesinin düşme hadisesi söz konusudur.

"l, r" gibi sesler Türkçe kelimelerin ilk seslerinde bulunmaz. Bundan dolayı bu seslerle başlayan yabancı kelimelerin başında bir ön ses " 1 " veya " $i$ ” türer. Metinde de buna örnek olarak ilāyık 24b-10 kelimesi bulunmaktadır.

Metinde yer değiştirme olayı, derviş $>$ devriş 9a-18, ug̉run $>$ urg்un 33a-5 (urḳun 70a-11 biçimiyle de geçmektedir.), ezke- > ekze- 53a-9 kelimelerinde görülmektedir.

Metinde ek uyumsuzluğu gösteren örnekler bulunmaktadır. Bunlar ise daha çok - $\dot{g} l l /$-gil emir

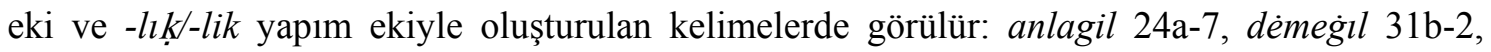
ķaşmagil 39b-2, ètğll 49b-4, çalgil 88b-2; dünyālik 1b-5.

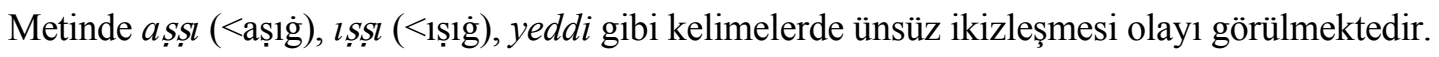

Metinde $b u$ işaret zamirinin çokluk hâli hem zamir n'li bunlar biçiminde, hem de Eski Türkçede görüldüğü gibi zamir n'siz bular şeklinde geçmiştir.

\subsection{Eserin Şekil Bilgisi Özellikleri}

Metinde geçen belirtme hali ekleri şunlardır: $-\imath /-i$, $-n \iota /-n i,-n$ ve ø. Bunlardan $-\imath /-i$, Eski

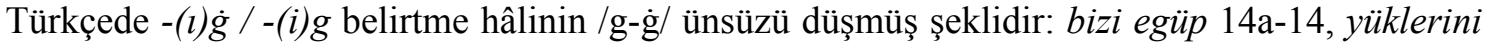
țutdllar 14b-1, ḳtșsasin èydem 1a-1, düşüy(i) de göreyüm 46b-10.

Yönelme hâli eki metinde, Eski Türkçede - $\dot{g} a /$-ge biçiminde olan -a /-e 'dir: allāha ıśmarladı 45a-8, gözine sürtdi 85b-2.

Bulunma hâli eki -da / -de'dir: cihānda çok idi 1b-5, düşümde gördügim 26b-6. Bulunma hâli eki, Eski Türkçede olduğu gibi ayrılma fonksiyonunda da karşımıza çıkmaktadır; anda küçük idi ne sāl 1a-12, ol șatanlarda haber söyleyesin 31a-15. Bu ek bulunma ve ayrılma fonksiyonundan başka az da olsa yönelme fonksiyonuyla da görülmektedir: geldi dünyāda yürür ḩūrīidi 2a-2, yazllarda varalum oḳ atalum 4a-2.

Metinde ayrılma hâli eki -dan / -den'dir: hakkkı bāṭldan seçüp 1a-8, uyḳusından uyanup 2a7. "Acından öl-" deyimi metinde "acın öl-" biçiminde ayrılma hâli eki getirilmeden eksiltili bir ifadeyle kullanılmıştır: hapse ḳoyam anda acın ölesin 43b-5.

Metinde vasıta hâli eki çoğu kez bağlama edatı olan "ile” ile karşılanmakla birlikte bir yerde ilen 12b-6 şeklinde geçmektedir. Yine az da olsa kalıplaşmış olarak $-n$ vasıta hâli ekini de görmekteyiz: aylan yıldızlar 2b-4, cümle ilen 12b-6, gündüzin yürürdi 16b-10, anuyla diridür 
17b-12, d̦arp ile 5a-18, 'aş ḳuile yanayum 23b-5.

Yön ekleri -ra / -re ve -aru / -erü ekleridir: șonra 1a-7, üzre 31a-11, içre 89b-2, țaşra 92b-1; ilerü 12a-3, berü 26a-16, ḳancaru 36b-3, yu ḳaru 51a-17, gerü 59a-17, içerü 77b-12.

Metinde soru eki olan $\mathrm{m}$ / mi, hep düz ünlülü bir biçiminde kaşımıza çıkmaktadır: revā mıdur 5a-2, dügün midür 8a-3, korḳmaduך mı 9a-5, var mı 12b-14, delü midür, 12b-17, var mıdur 31b-8, verrdi mi 64b-10, bildü円üz mi 80b-14.

Metinde aitlik eki genel itibariyle -ki'dir. Eski Türkçede görülen - $k \imath$ eki sadece kanḳı 21a-13 kelimesinde karşımıza çıkmaktadır. Bunun dışında tüm kelimelerde kalınlık-incelik uyumuna bakılmaksızın hep ince sıradan -ki eki kullanılmıştır: içindeki yüregim 17b-11, kendü ilindeki 21a-2, dīāarındaki țaşlar 73b-10.

Metinde geçen belirsizlik sıfatları bir, birķaç, ķamu, her, her bir, nece, neçe, cümle, fülān, hìç, hep, buncadır: bunca yıllık 4b-13, hep țonlarını 44a-6, hiç bulut 10a-17, fülān gāāra 96a-5, cümle ' ālem 1a-6, nece düş 3a-13, neçe fersah 54a-7, her bir sözi 28a-11, her yana 5a-11, ḳamu evlādından 1b-3, birksaç gün $7 \mathrm{~b}-7$.

Metinde geçen dönüşlülük zamirleri öz, kendüz ve kendü'dür: özün gaflete șalmışdı 1b-13, kendüzin gören 18b-11, kendü gizini 11b-6.

Metinde geçen belirsizlik zamirleri kim, kimi, kimisi, kimse, kimsene, her ki, her kim, her kişi, biri, birisi, bir kişi, her biri, her birisi, ayruk, ne kim, her ne, kुamu, cümle, hiç kimse, hịç birisidir: kimde ki 9b-4, hiç birisine 16b-16, hiç kimseye 31b-1, cümlemüz 5b-5, ķamus1 tagladılar 43a-20, her neyse 46b-15, ne kim yazdı 76b-9, ayruga varma 26b-15, her birisi 7b-8, her birimüz 12b-3, bir kişi èydür 87b-10, kimsene baḳmadı 76a-2, kimsenüy sırrını 2b-15.

Metinde geçen yer ve yön zarfları ḳanda, ḳarşu, içerü, țaşra, berü, ilerü, ortada, üzre, gèrü,

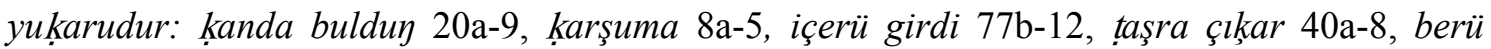
gelgil 83b-5, ilerü geldi 12a-3, ortada altun ḳadeḥler, dizi üzre oturur 31a-11, gèrü çeker 39b17, yukarudan 10b-14.

Metinde çeşitli miktar zarfları bulunmaktadır. Bunların bazıları sıfatlardan yapılmıştır, bazıları ise kelimenin tekrar edilmesiyle oluşturulmuştur. Bu zarflar şunlardır: key, katı, çok, şol

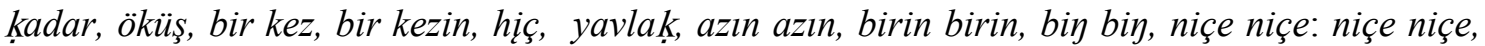

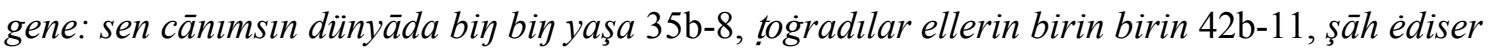
seni azın azın 20a-4, yavlak baḳa 7a-15, hiç ögüt thutmaz 54a-4, bir kezin gören kişi anı toymazdı 20b-5, ayda bir kez kişneridi ol atı 56b-17, gün öküşdür 11a-6, şol kadar kim sulțānı 'āşı ke eder 25a-5, çok yalvarur 6b-12, katı ḳorḳtdılar 12b-8, key bekleyesin 3a-1.

Metinde Türkçe ve yabanc1 asıllı pek çok zaman zarfı geçmektedir. Bunlardan bazıları şunlardır: dün gün, yarın, şimdi, gece, dün gündüz, gèce gündüz, ahşam, subḥ, ayruk, yene, șonra, andan soyra, dā'imāa: dā'imā kuzı gibi güdmişdi 2a-3, andan soyra gör neyledi ol hemān 22a-1, șonra kanuma benüm girmeyesin 24b-5, züleyhā döndi yene geldi evine 44a-1,vèrmezem bunı size ayruk dilemey 65a-7, geçdi gèce çün șubh oldı tog்dı güneş 15a-13, aḥsam oldı gün uyaḳd mag̀ribe 8a-7, gèce gündüz 'aş kla yeldürür 55a-13, dün gündüz èder baya 'izzetim 71b13, mıṣr pādişāhı bir gece meger 51a-8, dün gün dileye 18a-4, yarın atam yüzine neçe baḳam 39a-13, dèdiler şimdi bunı biz nédelüm 5a-12.

Metinde nite, neçün, nece ve ḳancaru soru zarfları geçmektedir: nitesin kardaşcugium 9b-17, neçün geldük 4b-2, nece vaș èdem 67a-10, ben garib ḳancaru ḳaçup gideyüm 27a-6.

Metinde bulunan ünlem ve çağırma edatları eyā, ey, hey, i, āh, vāy, haşāa, uş, uşda, dirīigādır: eyā cānım cānı 23b-16, hey utanmazlar 74a-7, i yār 4b-15, top cigerim yakdı āh āh 41b-3, bir haber geldi yene ey vāy 50b-3, beni nev-mīz eylemege senden ḥaşā 59a-4, uş getürdüm seni 
yoldaşlaruja 66b-9, uşda bundadur 67b-3, ey dirìgā atamuz bunda degil 81b-8.

Metinde kelimeleri, kelime gruplarını ve cümleleri birbirine bağlayan Türkçe ve yabancı asıllı birçok edat kullanılmıştır: ile, kim, ki, vü, u, ü, içün, çün, çünki, çünkim, ger, eger, meger, illā, gerçi, hem, hergiz, imdi, nitekim, şöyle kim, tā kim, gāh...gāh. züleyhāa ile kim murādına dege 60a-15, geldi gördi kim hezārān dürlü halk 29b-5, dèdi ki var bahāsin sen biç dedi 29b-13, getdi gönlünden belā vü derd ü ġam 85b-3, yūsuf içün baya nesne söylemey 4a-9, çün şerbetdār bunı işidür varur 52a-10, çünki bunlar evlerine vardılar 76b-15, yeddi yıl devrānı çünkim devr ède 52b-9, bir kişi ger kim atına bine revān 83a-4, eger yalanla bu şehre gelevüz 73b-11, illā birḳaç keleci saya dèdi 48a-18, gerçi bir şahs-ı mu'ayyen yok durur 95b-6, hem ulular meclisinde söylene 1a-4, şöyle kim mıșrda sarāy çog̀idi 37a-7, tā kim ol șürete çok yalvarur 3a-17, gāh başı iner gāh ayag்̀ döner 7a-2.

Metinde geçen son çekim edatları gibi, ile, bile, içün, içre, tā, -a dek, -den özgedir: ḳuzı gibi güdmişdi 2a-3, anlar ile 14a-1, benüm içün 36b-15, dẹiz içre 19b-9, tā sulțān öle siz anda turuy 45b-12, şuna dek 6b-9, senden özge 5b-16.

Metinde şimdiki zaman için ağız özelliği olarak düşünebileceğimiz şöyle bir kullanım bulunmaktadir:

$$
\begin{aligned}
& \text { "Kỉe ugiruligi yapasın ana } \\
& \text { bil kim hoş gelmiy (كمى) bu işin baya"( 79a-13) }
\end{aligned}
$$

Metinde görülen geçmiş zaman eki $-d l /-d i$ 'dir. Eski Anadolu Türkçesinde 1. ve 2. teklik ve çokluk şahıslarda bu ek daima yuvarlak ünlülü görülmekle birlikte metinde yaygın olarak 3 . teklik ve çokluk ekinin dışında da düz ünlü kullanımına gidildiği görülmektedir: uyurdum 2a-9, kıldum 15a-9, oḳumışdım 7a-18, bilmedim 4a-13.

Metinde öğrenilen geçmiş zaman eki hep düz ünlülü -mış / -miş’tir. Sadece bir yerde aslında zarf fiil eki olan -üpdür ekiyle karşılanmıştır.

"dèdi varın içerü vèrin haber

kim gelüpdür kardaşı̇ ey şir ü ner”

Metinde gelecek zaman eki -ısar / -iser'dir. Çoğu kez de istek eki -a/-e ile karşılanır. gidiserem 31a-5, göndüriser 25a-9, yèyiser 47a-6.

\subsection{Eserin Söz Varlığı Hakkında}

Metin kelime yapımı ve türleri bakımından incelendiğinde Eski Anadolu Türkçesi özelliklerine sahip olduğu anlaşılmıştır. Eser sade ve akıcı bir dille yazılmıştır. Kullanılan yabancı asıllı kelimelerin çoğu günümüzde de bilinen ve kullanılan kelimelerdir.

Metinde geçen bazı ifadeler dikkat çekicidir. Örneğin "söylemek" manasındaki eyt- kelimesi metinde çok sık geçen kelimelerden biridir. Yine bu kelime metinde birbirine yakın beş beyitte $(2 a-9,2 a-10,2 a-11,2 a-15,2 b-11)$ ve görülen geçmiş zamanda, "y" sesi düşmüş bir biçimde karşımıza çıkmıştır:

2a-9 etdi yā baba uyurdum bir gèce bir `acāyib düş görmişem idim nece

2a-10 etdi og̉ul de göreyüm düşüni hayr ola tanrı onara işini

$\mathrm{Bu}$ örneğin dişında metinde yine ilgi çekici pek çok kelime bulunmaktadır. Bunlardan arkaik nitelikte sayılabilecek kelimeler şunlardır; alda- "aldatmak" (35b-11); yaldan- "aldanmak" (5a4); a anar "öte, ileriye doğru" (67a-17); aşa "aşağı" (74a-11); aşaġa "aşağı" (70a-11); alḳış 
"hayır duası" (74a-1); çav "şöhret, ün" (1b-17); dükeli "hepsi, bütünü" (27a-4); isde- "istemek"

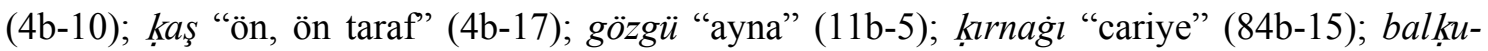
"parlamak, 1şık saçmak" (30b-7); barḳ "ev, mesken" (20a-14); bayl- "zengin olmak" (34a-12); berk ur- "şimşek çakmak" (87b-1); biti "yazılmış şey, mektup; belge" (13b-8); gözsüz "kör" (57b-16); ırga-" sallamak; kımıldatmak" (78b-14); oht "vakit" (70a-7); saġınç "düşünce, istek" (57a-14); șağı̧ "sayı, adet, miktar, hesap" (62b-10); șavuk "soğuk" (11a-9); semrit- "şişmanlatmak" (55b-1); perk "sağlam, sert" (30b-15); perkit- "sağlamlaştırmak" (23a-4); țam- "damlamak" (55b-10); sümük "kemik" (18b-14); yazkl "kader" (75b-4); üzgi "üzgü, sıkınt1, üzüntü" (94b-4); süd "süt” (40b-9); şaplag “şaplak"/ şapla (58a-1) "şaplak" (5a-15); üce “yüksek, en uç" (30a-13).

Metinde geçen bazı kelime ve ifadeler, kullanım sıklığı açısından hem tarihî metinlerde hem de günümüz Türkçesinde pek fazla rastlanılmayan türdendir: Bunlar: döşün vérmek (11a-6) "mola vermek"; ķara ḳura geçe göçe "değersiz, ıvır zıvır şeyler" (62a-2); düzdi koşdl" "tanzim etti; resmetti" (86a-2). Bazı kelimeler ise ağızsal özellikler taşımaktadır. Örneğin Farsçadan dilimize geçen "bagçe" (bahçe) kelimesinin metinde kalın sıradan bir şekilde "bakca" (34a-9) biçiminde geçtiği örnekler bulunmaktadır. Yine bu kelimeden türetilen "baģçe-vān" (bahçıvan) kelimesi bir yerde aynı anlamı veren Türkçe bir ekle daha türetilerek "bāg-vāncı" (60a-17) biçimde geçmiş olup "bakcavan" (34a-6) biçiminde kullanıldığ 1 örnekler de mevcuttur. Yine Arapça asıllı bir kelime olan "birțîl" (rüşvet) kelimesi metinde "barțll" (39a-16) biçimde geçmektedir. Bunun dişında yine ağız özellikleri taşıyan diğer kelimeler şunlardı: aḩran "yaşıt" (5b-5); a hş̧am "akşam" (8a-7); bilerzik (67a-12)/ bilerzük (66a-16) "bilezik"; delüh "delik" (6a13); esbāb (Ar. eșvāb) "giyecek şeyler" (89b-13).

Aşağıda bir takım ses olaylarına uğramış olup da başka bir yerde örneğine pek rastlanmayan kelimeler sıralanmıştır: yapça "yavaşça, sessizce" (95b-12); kapramak "kavramak" (93a-8); oḳa oka "ovarak, ova ova" (7b-11); pos "post" (61a-13); sepmek "serpmek" (26b-4); sigamak "sivamak, sivazlamak" (75a-2).

Son olarak Eski Anadolu Türkçesinin söz varlığında yer alan ancak kullanım sıklığı düşük olan kelimeler şunlardır: alu "aptal, sersem" (38b-3); başlu "yaralı" (69a-14); cāncuġaz "sevgili"" (34b-15); demleç "bilezik" (50a-16); dıĐsuzın "sessizce, yavaş sesle" (85a-15); dün buçuğ "gece yarısı" (10a-12); ensi endmek "aklı başından gitmek, sersemlemek, şaşırmak" (41a-2); geçmez aḳca "değeri çok düşük, kendisine itibar edilmeyen para" (13a-17); kaḳır buşamak "öfkelenmek" (15a-5); karıçı "yaş̧ı kadın” (58a-12); ḱcacuk "yaşlı erkek yaşlı" (8b-17); kुovcı "kovcu, dedikoducu" (2b-8); kizlık "kıtlı pahalılık" (52b-10); kişilemek "ağırlamak, ikram ve izaz etmek" (74a-9); șolu "solmuş" (79a-7); țulunmak "gözden kaybolmak" (20a-6); uyaḳmak "batmak" (8a-7); yalaşmak "öpüşmek" (14a-10); yepemek (16a-1) "okşamak".

Metnin söz varlığı istatiksel olarak değerlendirildiğinde ise şu sonuca ulaşılmıştır:

\begin{tabular}{|l|c|c|}
\hline Türkçe & 1334 & $\% 45$ \\
\hline Arapça & 1072 & $\% 36$ \\
\hline Farsça & 477 & $\% 16$ \\
\hline Arapça + Türkçe & 21 & $\% 0,7$ \\
\hline Farsça + Türçce & 18 & $\% 0,6$ \\
\hline Farsça + Arapça & 33 & $\% 1,1$ \\
\hline Arapça+ Farsça & 9 & $\% 0,3$ \\
\hline
\end{tabular}




\begin{tabular}{|l|l|l|}
\hline Toplam & 2964 & $\sim \% 100$ \\
\hline
\end{tabular}

Metin (Söz konusu metnin muhtelif yerlerinden örnek beyitler seçilmiştir. (Didem Akyıldı,, "18. Yüzyıla Ait Bir Kıssa-yı Yûsuf (Giriş-Inceleme-Metin-Dizin)”. Akdeniz Üniversitesi Sosyal Bilimler Enstitüsü, Yayınlanmamış Yüksek Lisans Tezi, Antalya, Ocak-2012).

\section{Metin}

\begin{tabular}{|c|c|}
\hline $1 a-5$ & $\begin{array}{l}\text { ol zamān ya'kūb peygamber meger } \\
\text { șạhib idi cümle hayr ile şer }\end{array}$ \\
\hline $1 a-6$ & $\begin{array}{l}\text { ol șuhuf ki ibrāhìme inmişdi } \\
\text { cümle 'ālem ana inanmışdı }\end{array}$ \\
\hline $1 a-7$ & $\begin{array}{l}\text { sonra ishāk nebī kılmış 'amel } \\
\text { ol gidüp ya' kūba kalmışdı meger }\end{array}$ \\
\hline $1 a-8$ & $\begin{array}{l}\text { bu dahı anū ile hükm èder idi } \\
\text { hakkı bātıldan seçüp söyler idi }\end{array}$ \\
\hline $1 a-9$ & $\begin{array}{l}\text { on iki og̀lı var idi meger } \\
\text { her biri māhir bir şî́r-i ner }\end{array}$ \\
\hline $1 a-10$ & $\begin{array}{l}\text { her biri 'ilm içre bir șāhib-i kemāa } \\
\text { yok sahāvet bunlara hem mișāl }\end{array}$ \\
\hline $12 a-9$ & $\begin{array}{l}\text { geldük emdi yūsufun kardaşları } \\
\text { eydeyüm ki nece oldı işleri }\end{array}$ \\
\hline $12 a-10$ & $\begin{array}{l}\text { taga çıkuban yırakdan bakdılar } \\
\text { gözlerin ol kuyuya bırakdılar }\end{array}$ \\
\hline $12 a-11$ & $\begin{array}{l}\text { kāfile konmıs bakuban gördiler } \\
\text { taǵdan inüben ol araya geldiler }\end{array}$ \\
\hline $12 a-12$ & $\begin{array}{l}\text { geldiler yūsufi kuyuda bulmadılar } \\
\text { kārbān aldı yūsufi bildiler }\end{array}$ \\
\hline $12 a-13$ & $\begin{array}{l}\text { gördiler bir ulu kārbān yatur } \\
\text { mālı mülki bir nece hānümān yatur }\end{array}$ \\
\hline $12 a-14$ & $\begin{array}{l}\text { sordılar ki kārbān kanda gelür } \\
\text { eytdiler ki bunlar mıșrdan gelür }\end{array}$ \\
\hline $12 a-15$ & $\begin{array}{l}\text { dèdiler ki kārubānun bașı } \\
\text { bize göstürüy nicedür ol kişi }\end{array}$ \\
\hline $12 a-16$ & $\begin{array}{l}\text { aldılar melik katına vardılar } \\
\text { 'ākıbet işit gel neylediler }\end{array}$ \\
\hline $12 a-17$ & $\begin{array}{l}\text { vardılar melike vèrdiler selām } \\
\text { dèdiler kim bir kulumuz kaçdı benām }\end{array}$ \\
\hline $12 b-1$ & $\begin{array}{l}\text { tīz turun ol kulı çıarun berü } \\
\text { almayınca ol kul gitmezüz gérü }\end{array}$ \\
\hline $12 b-2$ & $\begin{array}{l}\text { gizlemen ol kulumuzı vèrüy bize } \\
\text { yoksa zahmet varur bizden size }\end{array}$ \\
\hline
\end{tabular}


12b-3 her birimüz pehlüvāndur pehlüvān pādişāhlar bizden isterler amān

12b-4 vér kulumuz yoksa na' ra ururuz vèrmez isen cümlenizi öldürürüz

12b-5 ol melik korkup bulara yalvarur çıkaruban yūsufi gèrü vèrür

19a-9 hak andan bir baliga ilhām èder yūsufa karşu gelür ikrām èder

19a-10 yūsufun ayagì altına gider yūsuf anun arkasinda oturur

19a-11 èydür ey güneş yüzlü paşa beni nevmiz eylemek senden ḥāşā

19a-12 ben depizde balıklar sultānıyım ben depizün serveri hem hănım

19a-13 neçe yıldur ben demizde tururum ol çalap dergāhına yalvarurum

19a-14 dilegim oldur ki bir ogul vère ben ölicek ol benüm yerim göre

19b-4 iki og̀lan vèrdi hak baliga $d u^{\prime} \bar{a}$ oldur kim ol göge aga

19b-5 son ucı ol iki balık büyüdi bu nice balıklar depizdeyidi

19b-6 Son ucı birisi yuddı yūnusı dahı deyeyim nece ol birisi

19b-7 dahı birisi süleymān yüzügin yudmışdı deniz içinde hazin

42b-4 Kişi vérüp oḳdı hătūnları züleyhā ḳatına getürdi anlan

42b-5 anlar ile züleyhā șoḥbet eyledi dürlü dürlü hon-1 ni 'met eyledi

42b-6 şol kadar hon dökdi ol 'avratlara ol 'avratlar bakdilar ni' metlere

42b-7 honı çünki yediler getürdiler her birine dürlü hil' at vérdiler

42b-8 ol lațîf tonları çün geyürdiler devletüy artsun dèü̈ben țurdilar

42b-9 züleyhā buyurdı turunc getürdiler her birinün ellerine verdiler

42b-10 züleyhāà èdür birer bıçak alup ben size ne derrisem anı kılun

42b-11 züleyhāa buyurdı turuncı kesün 
cümlẹiz bıçak hāàzır ḳılun

42b-12 başladı turuncı kesmege her biri işid emdi nolısardur bu sirrı

42b-13 züleyḩā yūsufa işāret eyledi işid imdi yūsuf anda neyledi

42b-14 açdı ol görklü yüzin anlara 'arż ḳldd anda ol hătūnlara

42b-15 her biri turunc dèyüben ellerin togradilar ellerin birin birin

42b-16 her biri delürüben na' ra urur yūsuf anlara bakup karşu țurur

42b-17 her biri vālih hayrān olur yūsufun yüzünden ser-gerdān olur

42b-18 her birisi ellerin togradılar züleyhă uğraduġına uǵradılar

43a-1 yūsuf anda nikāāb örtdi yüzine ol hătūnlar geldiler kendüzine

43a-2 gördiler kim elleri olmış pāre pāre dédiler ağrısı anda yāre

43a-3 züleyhā èydür bildü̈üz mi derdimi kovlaşup 'ārsuz urduguz adımı

43a-4 bir bakış̧da şöyle mecrūḥ oldupuz kovlaşdunuz siz noldunuz

43a-5 ben bunun her dem görürüm yüzini işidürem ol şekerlü sözini

43a-6 fikr èdün kim benüm ḥālim nedür işbu 'aş̧ kim bende vardur kimdedür

43a-7 ol ḩātūnlar kamusin unutdılar şöyle kim her biri oda yandılar

43a-8 dèdiler kim ey hāatūn șuç eyledük senüniçün ḳovlaşup biz söyledük

43a-9 bizüm emdi scuçumuz bağışlagìl sana ne lāyık ise işlegil

43a-10 züleyhāa anlarun șuçların bağış̧ladı anlara ol gün keremler işledi

84b-13 döndi 'avrat beşî̀re vèrdi cevāb ey cüvān negü rūz negü şeb

84b-14 süd emerken ya'kūb og̀lancugiumu benden ayırdı șatdı cānumı

84b-15 ya'kūbun evinde ben kıınagityım kulluk èderim hem-rāhım

92b-10 mālik-i reyyān ile yūsuf meger 
çıkdılar ya' kūbuy evinden bi-haber dehşetinden ol nebininin şāh-1 dīn kendüzin ol dem unutmışdı yakịn

92b-12 geldi devlet hānına çün düşdi ol diledi köşke çıka ol pür ușūl

92b-13 tā teferrüc ḳla ol oğlanları kim nece oynarlar ol arslanları

92b-14 yūsufile gidiyken nāgehān ayağı degdi țaşa şāh-ı cihān

92b-15 ol degirman taşını dédim saya işid emdi neyler ol yūsuf ana

92b-16 bir eliyle kaldurdı ol șāh-1 cihān ol taşı getürdi ol zamān

92b-17 ḳoluna șaldı anı ol cüvān yeddi adım yere atdı revān

93a-1 gördi sulțān anı anda şāh-1 dīn yūsufa ḳıldı hezārān āferīn

93a-2 dèdi zihì ḳuvvet zihì hüsn-i cemāl bir yere cem' eylemiş ol zü 'l-celāl

93a-3 yūsufile köşke çıḳdı bir zamān ejderhā gibi geldi og̀lanlar revān

93a-4 șaf țtup sultāna karşu durdilar hoş du' ā kilup yüz yere urdılar

93a-5 anlara emr eyledi sultạn ol zamān țaşlara zor eylesün her bir cüvān

93a-6 yürüdi ol dem şem'ūn hemān bir eliyle dutdı țaşı pehlüvān

93a-7 taşları ol dem havāya bì-amān ḳarşu durdı ol yehūzā pehlüvān

93a-8 kapradı komadı düsmege yere gel teferrüc eylegil ol servere

93a-9 taşları 'ayyūka atdı yene kendüzi dutdi yene atdı yene

93a-10 dutdı pes şem' ūna ḳarşu țaşları ol pelengi gör ne işler işledi

93a-11 ol birisi karşu țutar heybetle ol yehūzāya tọgnn atar

93a-12 degdiler ol iki taş birbirine bakasin ol arsanlarin tedbirine

93a-13 pāre pāre oldı șanki esbāb neçe münkirler ol gün oldı harāb

93a-14 çünki yehūzāşem'ūn darıldılar 
niçe og̀lanlar araya girdiler

93a-15 her biri bir țas eline aldilar birbiriyle temāşā ḳıldılar

93a-16 ol țaşlan havāya atar bu atınca ol biri yene tutar

93a-17 bu dutunca ol dahı yene atar ol bu dahı yene tutar

93a-18 bir zamān bu nev' cevelān etdiler mālik-i reyyānı hayrān etdiler

93b-1 çünki sultāan eyle gördi anları yūsufa dèdi kim ey din serveri

93b-2 göndüresin rūma bunları nola kendüsi çün her biri bir şehr ala

93b-3 dèdi kim buyrug senün ey şāh-vār sen dejyecek anlarun ne sözi var

93b-4 hükm kildı tā ki rūma varalar anlar eyle varuban ceng édeler

93b-5 çünki destūr oldı ol şāh-zādeler ata katına gelüp izinn diler

93b-6 atadan himmet $d u^{\prime} \bar{a} s i n$ aldilar kendülerin rūm iline göndürdiler

93b-7 birbirinden andan oldılar cüdā her biri bir şehr içün ey kethüdā

93b-8 girdi rūm iline on bir cüvān șanasin girdi każā-yı āsmān

93b-9 her biri on bin eriyle ceng èder yéryüzüni bunlara ger teng èder

93b-10 feth-nāme geldi sultāna tamām kim vilāyet sana dutdı ey hümām

99b-17 yā ilāhī sen bilürsin hạlimi bana hācet söyleyem ahvālimi

100a-1 mücrimim başdan ayaġa pür günāh sen kerīmsin bì-niyāz pādişāh

100a-2 raḥmetün deryāsınun pāyānı yok hod benüm 'aczimden özge nesne yok

100a-3 ne dil ile hażrete söz söyleyem benüm cürmime bārì ‘özr eyleyem

100a-4 cismüm cānum ḳılmiş cürm-i hațā tā meger senden ola fázl-1 'ațā

100a-5 ben fakìïüm sen ganisin ey hudā ayırma beni raḥmetinden cüdā

100a-6 i'timād èdecek bir 'ilmüm yok 

hażretine gidecek 'amelüm yok
100a-7 budur senden temennām ey hudā
kılmayasin bizi al aḥmedden cüdā
100a-8 ma'nāda ger vāḳı' a olduysa hațā 'afv k1l külli cürmümi vèrgil 'atāa
100a-9 bakma sen sehv-i hațām yā kadìm eyle kabūl ḥażrete şāh-1 nedìm

100a-10 kātibe vèrgil sen 'ațā cürmini sen 'afv eylegil 'ațā

100a-11 bunı yazdum bī-vefădur mürūr-kār ben ölende kala hatm-i yād-gār

100a-12 fă ilàt fă'ilāt fă ilāt bin günāhı def éder bir șalavāt

100a-13 yazanı okuyanı dipleyeni raḥmetinle yarligagìll yā gan $\bar{i}$

100a-14 dünyādan getmümizi fikr èdülüm șādıkāne hāạlı zikr èdelüm

100a-15 her kim ister rahmeti çok kazana fătiḩa okuya bunı yazana

100a-16 el-fakir el-hakìir' 'abd-i'āciz'abd-i ża'if el-müznib el-muhtāc ilā rabbihi

100a-17 el-lugat-i ketebehū muhammed bin hüseyn gaferu'l-lāh lehü ve livālideyni ve li cemī ' ̈̈̈'l-mü'minninn. 


\section{KAYNAKÇA}

Arat, R. (1987). “Anadolu Yazı Dilinin Tarihi İnkişafına Dâir”. V. Türk Tarihi Kongresi, Makaleler, Cilt 1, 225-232 Ankara: Türk Kültürünü Araştırma Enstitüsü Yayınları.

Ayan, G. (1997). “Ahmet Yesevi Etkisiyle Yazılan İki Yusuf u Züleyha”. Türkiyat Araştırmaları Dergisi, 3, 31-38.

Ayan, G. (2009). “Anadolu Sahasında Yazılan Bazı Yusuf ve Züleyha Mesnevilerinde Sebeb-i Telifler”. Turkish Studies, vol. 4/3, 227-272.

Caferoğlu, A. (1984). Türk Dili Tarihi. İstanbul: Enderun Yayınları.

Canpolat, M. (1991) “Arap Yazılı Türk Alfabesinin Gelişmesi”. Harf Devrimi’nin 50. Yılı Sempozyumu, 49-50. Ankara: Türk Tarih Kurumu Yayınları.

Cin, A. (2004). “Ali’nin Kıssa-i Yûsuf Adlı Eserinin Türkiye Yazması”. V. Uluslararası Türk Dili Kurultayı Bildirileri, Cilt I. 20-26 Eylül 2004. Ankara: Türk Dil Kurumu Yayınları.

Cin, A. (2011). Türk Edebiyatının Illk Yusuf ve Züleyha Hikâyesi, Ali’nin Kıssa-i Yûsuf'u. Ankara: Türk Dil Kurumu Yayınları.

Cin, A. (2012). İbni Abbas'tan Rivayet Edilen Yûsuf ve Züleyha Hikâyesi. Antalya: Akdeniz Üniversitesi Yayınları.

Cin, A. (2012). "İran Coğrafyasında Hz. Hüseyin Yası ve Bir Kerbela Kıssası”. Türk Kültürü ve Hacı Bektaş Veli Araştırma Dergisi, 63.

Çağatay, S. (1944). "Eski Osmanlıca Üzerine Bazı Notlar". Türkoloji Dergisi, Cilt II, (2), 297-312.

Çelebioğlu, A. (1999). XV. Yüzyıla Kadar Türk Edebiyatında Mesnevi. İstanbul: Kitabevi Yayınları.

Çetin, N. (2000). "Yeni Türk Şairinin 'Yûsuf ve Züleyhâ Hikâyesi Duyarlılığı". Türkoloji Dergisi, Cilt. XIII, I, 109-143.

Çetinkaya, Ü. (1995). Aşk Mesnevilerinde Kadın, Yusuf u Züleyha ve Hüsrev ü Şirin Mesnevileri. Yayınlanmamış Doktora Tezi. Ankara Üniversitesi, Sosyal Bilimler Enstitüsü, Ankara.

Develi, H. (1995). Evliya Çelebi Seyahatnamesine göre 17. Yüzyll Osmanlı Türkçesinde Ses Benzeşmesi ve Uyumlar. Ankara: Türk Dil Kurumu Yayınları.

Doğan, E. (2011). Şeyh Sadrüddin'in Kabus-nâme Tercümesi. İstanbul: Mavi Yayıncılık.

Dolu, H. (1952). "Yusuf Hikâyesi Hakkında Birkaç Söz ve Bazı Türkçe Nüshalar". Türk Dili ve Edebiyatı Dergisi, Cilt 4, 419-445.

Dolu, H. (1954). "Yûsuf Hikâyesinde Aşk Temi”. Türk Düşüncesi, Cilt 1, 2.

Ertaylan, İ. (1948). "Türk Dilinde Yazllan İlk Yûsuf ve Züleyhâ". İstanbul Üniversitesi Türk Dili ve Edebiyatı Dergisi, Cilt III, (1-2), 211-231.

Gümüşkılıç, M. (2008). “Orta Osmanlıcada İmla-Telaffuz İlişkisi”. Turkish Studies, 3/6, 286-302.

Karahan, L. (1994). Erzurumlu Darir, Kıssa-yı Yûsuf (Yûsuf u Züleyha). Ankara: Türk Dil Kurumu Yayınları.

Levend, A. (1967). "Divan Edebiyatında Hikâye”. Türk Dili Araştırmaları Ylllı̆̆ı Belleten, 71-117.

Levend, A. (1968). "Hamdi’nin Yûsuf u Züleyhâsı". Türk Dili Araştırmaları Ylllı̆̆ Belleten, 157-172.

Özkan, M. (1995). Türk Dilinin Gelişme Alanlart ve Eski Anadolu Türkçesi. İstanbul: Filiz Kitabevi.

Özkan, M., \& Tören, H. (2012). Osmanlı Türkçesi II. İstanbul: Akademik Kitaplar Yayınevi.

Türkdoğan, M. (2011). Klasik Türk Edebiyatında Yusuf u Züleyha Mesnevileri Üzerine Mukayeseli Bir Çalışma. Ankara: Kültür ve Turizm Bakanlığı Yayınları. (http://ekitap.kulturturizm.gov.tr/dosya/1281553/h/klasik-turk-edebiyatinda-yusuf-u-zuleyha-mesnevileri-uz-.pdf)

Yıldız, O. (2008). Şeyyad Hamza, Yûsuf u Zelîha (Destân-ı Yûsuf) Giriş-İnceleme-Metin-Dizinler. Ankara: Akçağ Yayınları. 